\title{
Desain dan Optimasi Primer Gen Pengkode MRPA Trypanosoma evansi dan Penerapan pada Pembelajaran Biologi Molekuler
}

\author{
${ }^{1 *}$ Moh. Mirza Nuryady, ${ }^{1}$ H. Husamah, ${ }^{1}$ Fuad Jaya Miharja, ${ }^{1}$ Iin Hindun, \\ 2P. Patmawati
}

\begin{abstract}
${ }^{1}$ Prodi Pendidikan Biologi, FKIP, Universitas Muhammadiyah Malang, Jl. Raya Tlogomas No. 246, Malang, Jawa Timur, 65144, Indonesia

2Prodi Magister Pendidikan Biologi, Program Pascasarjana, Universitas Muhammadiyah Malang, Jl. Raya Tlogomas No. 246, Malang, Jawa Timur, 65144, Indonesia
\end{abstract}

*Corresponding Author e-mail: mirzanuryady@umm.ac.id

Received: June 2020; Revised: June 2020; Published: July 2020

\begin{abstract}
Abstrak
Penelitian molekuler untuk menemukan gen pengkode resistensi Multidrug Resistance Prtotein A (MRPA) T. evansi dan perbanyakan gen secara Polimeration Chain Reaction (PCR) masih sedikit dilakukan dan sangat penting untuk dipahami oleh mahasiswa calon guru biologi. Kajian ini bertujuan untuk menganalisis proses desain dan optimasi primer untuk gen target MRPA T. evansi yang dapat digunakan sebagai sumber belajar mahasiswa pendidikan biologi. Penelitian ini merupakan penelitian deskriptif mengenai tahapan mendesain primer secara online, optimasi primer secara laboratorium serta kajian mengenai pentingnya penerapan hasil studi ini dalam pembelajaran. Hasil penelitian menunjukkan terdapat tiga desain primer yang memenuhi syarat, selanjutnya dari tiga primer tersebut hasil optimasi di laboratorium menunjukkan hanya terdapat dua primer yang menunjukkan hasil yang baik dan dapat digunakan untuk penelitian amplifikasi gen MRPA T. evansi, yaitu primer pertama (F1', R1') dan primer kedua (F2', R2'). Hasil kajian desain dan optimasi primer ini menunjukkan bahwa mahasiswa pendidikan biologi sangatlah penting untuk memahami konsep terkait dengan pekerjaan molekuler seperti mendesain dan optimasi primer, dikarenakan mereka memiliki tuntutan untuk menjadi seorang calon pendidik atau sebagai calon peneliti di masa depan.
\end{abstract}

Kata Kunci: Gen MRPA, Primer, Sumber belajar, Trypanosoma evansi

\section{Design and Optimization of Trypanosoma evansi MRPA Primer Coding Genes and Application to Molecular Biology Learning}

\begin{abstract}
Molecular research to find Multidrug Resistance Prtotein A (MRPA) resistance coding genes and gene propagation by Polimeration Chain Reaction (PCR) is still little done and is very important to be understood by prospective biology teacher students. This study aims to analyze the design and primary optimization process for the T. evansi MRPA target gene that can be used as a learning resource for biology education students. This research was a descriptive study to described the step of primer design and optimization due to the importance of this steps to be applied as learning source. The results showed that there were 3 primer designs that qualified, then after the optimizing step there were only two primers that showed a good result, the first primer (F1, R1) and second primer $(F 2 ', R 2)$. The results of this study showed the importance of biology education students to understand the concepts related to molecular work because in the future they are not only become prospective educators, they also have demands as prospective researchers.
\end{abstract}

Keywords: Gen MRPA, Learning resource, Primer, Trypanosoma evansi

How to Cite: Nuryady, M., M., Husamah, H., Miharja, F., J., Hindun, I., \& Patmawati, P. (2020). Desain dan Optimasi Primer Gen Pengkode MRPA Trypanosoma evansi dan Penerapan pada Pembelajaran Biologi Molekuler. Jurnal Penelitian dan Pengkajian Ilmu Pendidikan: e-Saintika, 4(2), 223-233. doi:https:// doi.org/10.36312/e-saintika.v4i2.217 


\section{PENDAHULUAN}

Cabang ilmu Parasitologi dan Biomolekuler dalam keilmuan Biologi sangatlah berhubungan erat (Bass, Stentiford, Littlewood, \& Hartikainen, 2015; Kochin, Bull, \& Antia, 2010), hal ini di dasarkan pada salah satu teknik diagnosis atau identifikasi parasit yaitu dengan teknik molekuler (Dewi, Wardhana, Ekawasti, \& Sawitri, 2020). Trypanosoma evansi (T. evansi) merupakan salah satu parasit yang menginfeksi hewan atau dikenal dengan penyakit surra (Wardhana, Merlina, \& Subekti, 2014). Meningkatnya kasus infeksi T. evansi ini mengakibatkan seringnya penggunaan obat trypanosidal yang berakibat pada munculnya kasus resistensi T. evansi terhadap obat tertentu. Menurut Delespaux, Geysen, Majiwa, dan Geerts (2005), salah satu gen yang bertanggung jawab terhadap kasus resistensi adalah gen pengkode Multidrug Resistance Protein A (MRPA). Metode molekuler yang digunakan untuk mengisolasi gen tersebut adalah dengan prinsip Polimerase Chain Reaction (PCR).

Teknik Polymerase Chain Reaction (PCR) adalah teknik sintesis dan amplifikasi rantai Dioxyribonucleic Acid (DNA) dalam jumlah banyak dalam waktu singkat (McPherson \& Møller, 2007). Teknik PCR dilakukan secara in vitro menggunakan reaksi enzimatis pada potongan DNA yang pendek sebagai cetakan. Prinsip terjadinya reaksi dalam PCR adalah dengan adanya sifat komplementer antara rantai DNA target melalui bantuan enzim polimerase, deoksiribonukleotida trifosfat (dNTP), buffer PCR, magnesium klorida dan oligonukleotida sebagai primer yang ketika semua dicampurkan reaksinya akan dipicu dengan perubahan suhu di dalam mesin thermocycler (Handoyo \& Rudiretna, 2000). Bagian sekuen DNA target yang akan diamplifikasi harus diketahui terlebih dahulu sebelum dilakukan amplifikasi dengan mendesain primer forward $\left(\mathrm{F}^{\prime}\right)$ dan primer reverse $\left(\mathrm{R}^{\prime}\right)$ yang sesuai. salah satu faktor penting dalam keberhasilan PCR adalah pemilihan primer yang memiliki sensitifitas dan spesifisitas yang tinggi.

Primer berperan penting dalam penempelan pada daerah spesifik cetakan DNA dan juga mengawali sintesis rantai DNA selanjutnya. Primer merupakan urutan sekuen basa oligonukleotida pendek, umumnya berukuran 18-25 basa nukleotida. Ukuran primer yang terlalu pendek krang dari 18 basa akan menurunkan spesifitas karena primer akan menempel di sembarang tempat (misspriming). Primer forward akan menempel pada ujung DNA 5'-fosfat yang komplemen dengan bagian dari cetakan DNA. Primer reverse akan menempel pada ujung rantai DNA antisense 3'$\mathrm{OH}$ dan hasil sintesis rantai ini akan membentuk rantai okazaki karena arah sintesis rantai baru oleh enzim polimerase berjalan dari ujung 5' menuju ujung 3' (Sambrook \& Russel, 2001; Yuwono, 2006). Desain primer dilakukan berdasarkan data DNA target yang bisa dilihat di Gene Bank, namun apabila belum diketahui primer dapat didesain dengan menggunakan urutan basa DNA spesies yang berkerabat dekat dengan spesies target. Proses selanjutnya setelah melakukan desain primer adalah optimasi primer dengan melakukan uji trial and eror (Dewi et al., 2020), hal ini bertujuan untuk mendapatkan primer terbaik yang akan digunakan dalam melakukan isolasi DNA dalam prinsip molekuler.

Pembelajaran untuk calon guru biologi di jenjang SMP da SMA harus mengembangkan minat dan antusiasme mereka terhadap biologi dalam berbagai konteks yang merangsang keingintahuan, relevan, dan menyenangkan. Hal ini juga memungkinkan fleksibilitas dan personalisasi dengan menawarkan pilihan konteks untuk dipelajari. Keahlian penyelidikan dan investigasi ilmiah perlu dikembangkan sepanjang perkuliahan. Ini akan memungkinkan para mahasiswa untuk menjadi warga negara yang melek secara ilmiah (scientifically-literate citizens). Perkuliahan ini 
memungkinkan para mahasiswa untuk mengembangkan pemahaman yang lebih dalam tentang tema-tema biologi yang mendasarinya. Skala topik berkisar dari molekuler hingga keseluruhan organisme dan seterusnya (Scottish Qualifications Authority, 2019). Mahasiswa perlu memiliki literasi genetic, berupa tiga model terintegrasi, yaitu model genetik (pola pewarisan genetik), model meiosis, dan model molekuler (mekanisme menghubungkan genotipe dengan fenotipe) (Maryuningsih, Hidayat, Riandi, \& Rustaman, 2020). Beberapa materi yang dapat dipelajari yaitu keadaan materi dan ikatan dalam kaitannya dengan perilaku dan energi molekul; genetika molekuler dan penurunan sifat serta mekanisme modifikasi genetik; dasar molekuler untuk teori dan klasifikasi evolusi; struktur dasar atom dan molekul; teori orbital molekul, aromatik, struktur logam dan ion, dan korelasi dengan sifat-sifat materi; reaktivitas kimia dan struktur molekul termasuk efek elektronik dan sterik; gerak kinetik-molekul dan model atom (National Science Teachers Association, 2003).

Penerapan pembelajaran molekuler sangat penting diberikan kepada mahasiswa program studi pendidikan biologi (Boulay, Parisky, \& Campbell, 2010; Keskin \& Özay Köse, 2017; Olander \& Olander, 2013), dikarenakan selama ini prinsipprinisp kerja molekuler dirasa sangat susah dipahami oleh mahasiswa (Suryanti, Fitriani, Redjeki, \& Riandi, 2019). Nurlaila, Sriyati, dan Riandi (2017) menunjukkan hasil bahwa sebagian besar mahasiswa pendidikan biologi masih mengalami miskonsepsi pada konsep-konsep genetika molekuler seperti DNA, gen, kromosom dan sintesis protein. Hal yang sama juga ditunjukkan pada penelitian oleh (Boulay et al., 2010) menemukan bahwa para guru tidak percaya diri dalam mengajarkan teknik - teknik biologi molekuler tertentu di kelas. Teknik seperti sentrifugasi, pemipetan, elektroforesis DNA, ligasi DNA, purifikasi DNA/plasmid, purifikasi protein, enzim restriksi, transformasi bakteri, PCR dan desain primer. Hal ini tentu menjadi pertimbangan untuk menjadikan teknik-teknik molekuler tersebut yang salah satunya adalah desain dan optimasi primer dapat diterapkan dalam pembelajaran mahasiswa pendidikan biologi.

Kajian ini bertujuan untuk menganalisis proses desain dan optimasi primer untuk gen target MRPA T. evansi yang dapat digunakan sebagai sumber belajar mahasiswa pendidikan biologi. Kajian ini berkontribusi pada pengembangan diskusi dan penggambaran alternatif fokus penelitian terkait dengan optimasi primer dan bagaimana kaitanya dengan pengembangan kompetensi calon guru biologi. Bila nantinya apabila kajian ini dilanjutkan menjadi penelitian maka penelitian ini merupakan penelitian pertama yang akan menjelaskan tentang desain dan optimasi primer yang dikaitkan dengan penerapan sumber belajar biologi. Kedepannya, hasil dari penelitian ini akan dapat membantu mahasiswa program studi pendidikan biologi dalam melakukan desain dan optimasi primer untuk penelitian molekuler lainnya.

\section{METODE}

\section{Persetujuan Etik}

Protokol eksperimental yang dilakukan telah sesuai dengan prinsip-prinsip perawatan hewan laboratorium, mendapatkan persetujuan dan pengawasan yang ketat oleh Komite Etik FKH-UGM dengan No. 0024/ EC-FKH/Int./2018.

\section{Metode Koleksi sampel T. evansi}

Mencit jantan dewasa (Mus musculus Balb-C) dengan berat antara 20-30 gram digunakan dalam percobaan ini. Selanjutnya, diinjeksikan Trypanosoma evansi 
sebanyak $10^{5}$ yang dilarutkan dalam 0.3 cc Natrium sitrat 3\% menggunakan spuit melalui intraperitoneal. Pengecekan derajat parasitemia dilakukan setiap hari dengan cara pengambilan darah melalui ekor mencit dan diamati di bawah mikroskop dengan perbesaran 1000x. Apabila ditemukan $>10$ T. evansi dalam satu luas bidang pandang menandakan derajat parasitemianya tinggi dan dilakukan koleksi T. evansi dengan mengambil darah tikus secara intracardial setelah mencit dieutanasi.

\section{Metode Isolasi Genom T. evansi}

Sampel darah mencit ditambahkan PBS sampai volume akhir menjadi $200 \mu 1$ dan dicampur, kemudian dipindahkan pada tube microsentrifus $1,5 \mathrm{ml}$, selanjutnya ditambahkan sebanyak $20 \mu \mathrm{l}$ proteinase $\mathrm{K}$ dan di vortex, kemudian diinkubasi pada suhu $60^{\circ} \mathrm{C}$ selama 5 menit, setiap 2 menit tube dibalik selama inkubasi. Larutan ditambahkan $200 \mu \mathrm{l}$ alkohol absolut kemudian divortex selama 10 detik. Kolom filter diletakkan pada tabung koleksi ukuran $2 \mathrm{ml}$, kemudian semua campuran pada kolom filter dipindahkan dan disentrifugasi pada 14-16000 x g selama 1 menit. Selama dilakukan sentrifugasi, jika campuran tidak mengalir ke membran kolom filter waktu sentrifugasi ditambah sampai campuran mengaliri membran dalam kolom filter tabung koleksi yang terisi dibuka, kemudian kolom filter dipindahkan pada tabung koleksi yang baru. Sebanyak $400 \mu \mathrm{l}$ W1 buffer ditambahkan pada kolom filter, disentrifugasi pada 14-16.000 x g selama 30 detik kemudian dibuang. Kolom filter diletakkan kembali pada tabung koleksi. Pada kolom filter ditambahkan $600 \mu \mathrm{l}$ wash buffer kemudian disentrifugasi pada 14-16.000 x g selama 3 menit dan dibuang. Kolom filter diletakkan kembali pada tabung koleksi, standar volume adalah $100 \mu \mathrm{l}$ (prosedur DNAeasy Kit Extraction, Qiagen).

\section{Metode Desain Primer online}

Tahapan awal desain primer yaitu dengan menentukan gen target di Gene Bank National Center For Biotechnology Information (NCBI), yaitu gen pengkode Multidrug Resistance Protein A (MRPA). Peneltian tentang MRPA T. evansi beum pernah dilakukan sehingga digunakan gen pengkode MRP dari Trypanosoma brucei (AJ318885.1) yang berkerabat dekat dengan Trypanosoma evansi. Ditentukan area yang akan dijadikan sebagai target isolasi PCR pada gen tersebut, pada penelitian ini ditetapkan panjang maksimal gen target adalah $>1000$ basepair (bp). Potongan gen target di proses dengan software onliePrimer3 web(version 4.1.0), gen target di paste pada kotak dialog (pada Gambar 1).

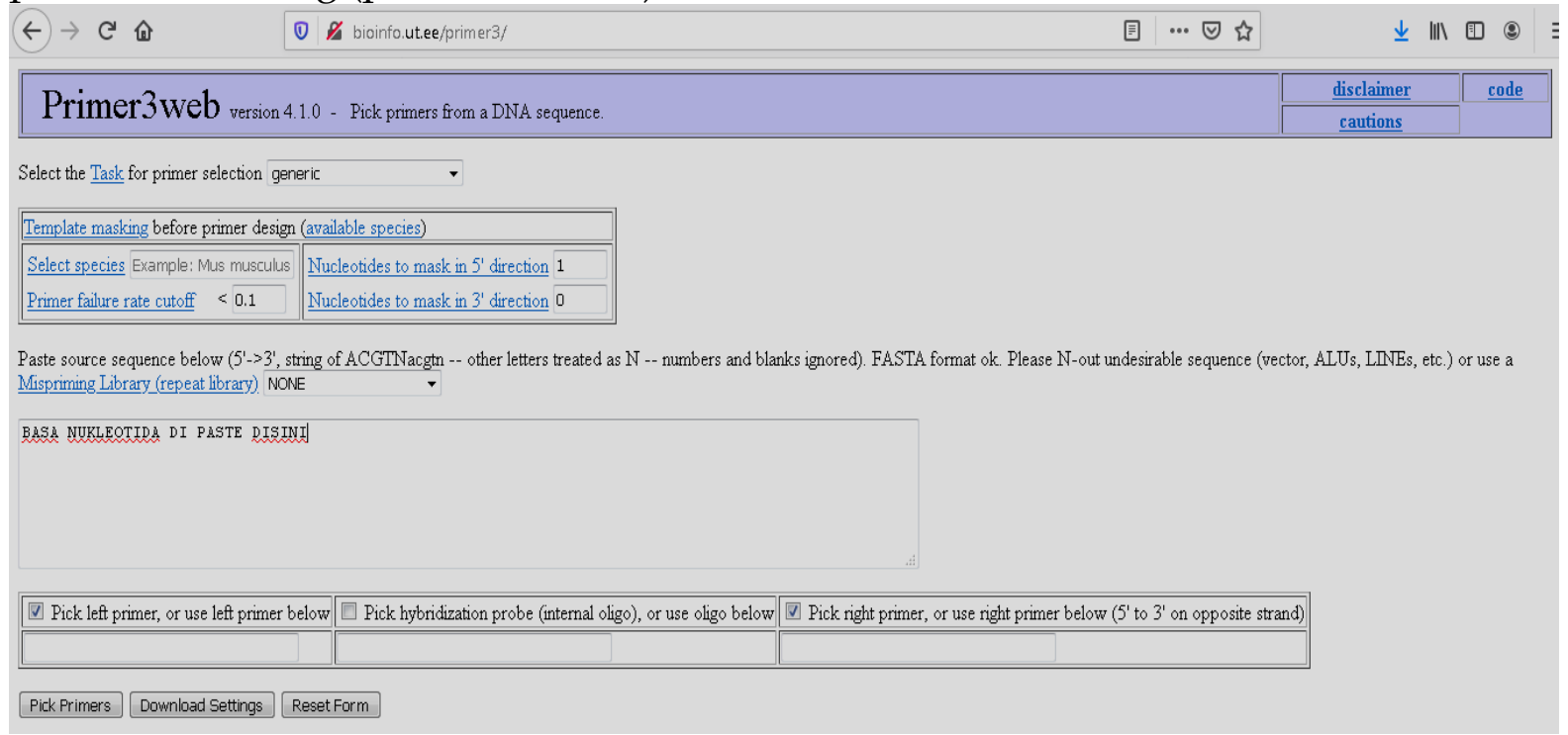


Tahapan selanjutnya sebelum diproses disarankan untuk mengatur ukuran produk amplifikasi gen target, ukuran panjang primer (minimal $>18$ bp dan maksimal $<30 \mathrm{bp}$ ), Primer Time Melting (Tm) yang disarankan berkisar $50-65^{\circ} \mathrm{C}$ dan jumlah GC primer berkisar 45-60\% (Gambar 2.), selanjutnya klik tombol pick primer. Primer yang sudah sesuai dengan persyaratan selanjutnya di cek menggunakan primer-BLAST. Isikan primer reverse dan primer forward pada sub judul "primer parameters" lalu pastikan pada sub judul "primer pair specificity checking parameters" kolom "database" telah diubah menjadi nr dan pada kolom "organism" dikosongkan kemudian klik tombol "get primers".

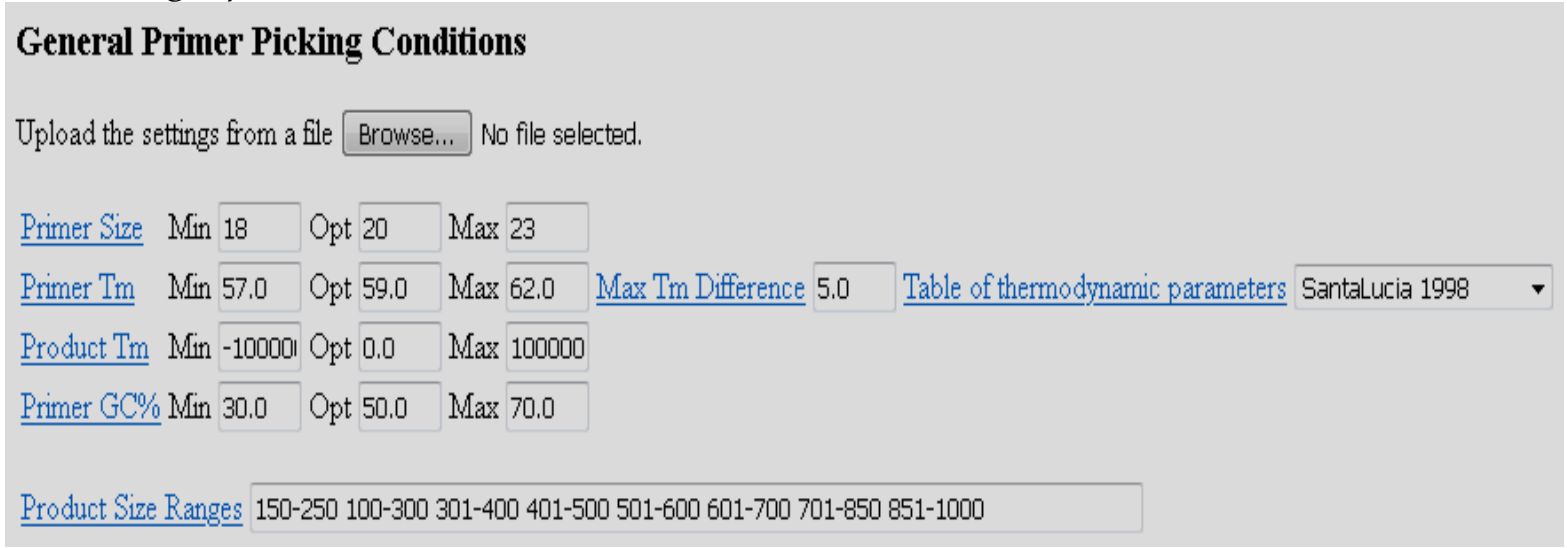

Gambar 2. Hal-hal yang perlu diperhatikan dalam desain primer online

\section{Metode Optimasi Primer secara laboratorium}

Campuran reaksi PCR dimasukkan dalam tabung mikrotub, yang terdiri atas 25 $\mu 1$ 2x Go Taq Green polimerase Master Mix, $10 \mu$ l template DNA, primer (F:1 $\mu \mathrm{l})$ dan distilled water 16-19 $\mu \mathrm{l}$ sehingga total volume $50 \mu \mathrm{l}$ campuran reaksi PCR dicampur sampai homogen menggunakan vortex, tabung mikrotub selanjutnya dimasukkan ke dalam mesin PCR. Optimasi dilakukan menggunakan PCR dengan setting suhu predenaturasi $94^{\circ} \mathrm{C}$ selama 5 menit, suhu denaturasi $94{ }^{\circ} \mathrm{C}$ selama 30 detik, suhu annealing yang digunakan dapat dihitung berdasarkan $(\mathrm{Tm}-5){ }^{\circ} \mathrm{C}$ sampai dengan $(\mathrm{Tm}+5){ }^{\circ} \mathrm{C}$, suhu elongasi $72{ }^{\circ} \mathrm{C}$ selama 1 menit dan post elongasi $72{ }^{\circ} \mathrm{C}$ selama 5 menit, dilakukan sebanyak 35 siklus (Njiru et al., 2005).

Hasil amplifikasi PCR yang telah dilakukan kemudian dikonfirmasi dengan elektroforesis gel agarosa $1 \%(\mathrm{~b} / \mathrm{v})$ menggunakan alat elektroforesis. Komposisi gel agarosa dibuat dengan melarutkan 0,3 gr agarosa dalam $30 \mathrm{ml}$ buffer TBE $1 \mathrm{x}$ ditambahkan cyber save flourescen 1,5 $\mu$ l. Larutan tersebut kemudian didihkan hingga semua agarosa larut sempurna, kemudian didinginkan hingga suhu larutan menjadi $60^{\circ} \mathrm{C}$. Setelah larutan dingin dituangkan ke dalam cetakan gel yang memiliki sisir sebagai cetakan sumuran. Pada sumuran gel dimasukkan $5 \mu l$ marker DNA yang telah dicampurkan dengan $1 \mu \mathrm{l}$ loading dye dan $7 \mu$ l sampel hasil PCR yang telah di campurkan dengan $1 \mu$ l loading dye. Proses elektroforesis dilakukan dalam TBE 1x sebagai media penghantar arus listrik tegangan 100V selama 45 menit. Hasil elektroforesis kemudian divisualisasi dengan lampu UV dan dianalisis dengan di foto. Sampel dinyatakan berhasil apabila didapatkan pita DNA pada 1000 base pair (bp).

\section{Analisis hasil penelitian dihubungkan dengan penerapan sumber belajar}

Penelitian ini merupakan penelitian deksriptif untuk mendapatkan primer terbaik dalam amplifikasi gen MRPA dari T. evansi, selanjutnya dihubungkan dengan penerapannya sebagai sumber belajar biologi. Berbagai referensi diperoleh dengan 
cara telusur Google terkait dengan topik kajian. Sebagian besar referensi adalah referensi primer berupa jurnal dan prosiding terindeks Scopus, jurnal terakreditasi SINTA, dan beberapa dokumen internasional lainnya yang mendukung kajian ini.

\section{HASIL DAN PEMBAHASAN}

Hasil penelitian desain primer secara online didapatkan setidaknya empat desain primer gen MRPA dari T. brucei yang sesuai dengan syarat primer. Syaratsyarat primer tersebut adalah panjang primer berkisar antara 18- $30 \mathrm{bp}$, primer mengandung $45-60 \%$ basa guanine $(\mathrm{G})$ dan sitosin $(\mathrm{C})$ dikarenakan ikatan antara G-C memiliki ikatan yang lebih kuat dibandingkan A-T. Primer juga harus memperhatikan Melting Temperature (Tm) antara kedua primer Forward dan Reverse tidak terlalu jauh perbedaannya. Perhitungan Tm pada masing-masing primer dapat dihitung menggunakan rumus $2(\mathrm{~A}+\mathrm{T})+4(\mathrm{C}+\mathrm{G})$ sehingga akan menghasilkan suhu untuk Tm. Di sisi lain urutan basa dalam primer juga harus diperhatikan agar terhindar dari interaksi antar primer sendiri yang sering disebut dengan self homology, cross homology, dan primer dimer (Handoyo \& Rudiretna, 2000). Keempat primer hasil desain online kemudian dilakukan Primer-BLAST hal ini bertujuan untuk mengetahui primer yang sudah di desain secara online dapat berikatan dengan gen target yang berada pada gene bank (Bedwell \& Goldberg, 2020; Ye et al., 2012). Hasil desain primer dari keempat primer hanya terdapat tiga primer yang merupakan hasil dari analisis primer Blast. Hal ini dikarenakan hanya tiga primer saja yang berikatan spesifik pada gen target yaitu MRPA T. brucei dan tidak berikatan dengan gen pada organisme lainnya.

Primer pertama memiliki panjang 21bp dengan GC\% 47.62 dan Tm left primer $60.00{ }^{\circ} \mathrm{C}$, Tm right primer $59.98^{\circ} \mathrm{C}$, F1' primer akan menempel pada sequence ke 1814 di rantai sense sedangkan R1' primer akan menempel pada sekuens ke 2826 pada rantai antisense. Hasil primer Blast menunjukkan primer ini akan menempel pada spesies yang spesifik yaitu gen MRPA T. brucei (Nomor Akses NCBI AJ318885.1,

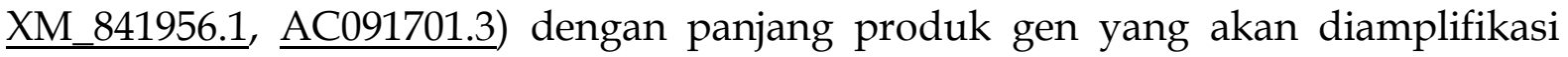
sebesar 1013bp. Hasil desain primer kedua memiliki panjang $21 \mathrm{bp}$, GC\% sebesar 42.86, Tm $56.97{ }^{\circ} \mathrm{C}$ untuk left primer dan Tm right primer sebesar $57.06{ }^{\circ} \mathrm{C}$. Hasil analisis primer BLAST untuk primer kedua menunjukkan primer ini spesifik terhadap gen MRPA pada T. brucei (XM_841956.1, AC091701.3, AJ318885.1) dengan panjang produk gen yang akan teramplifikasi sebesar 1216bp. Desain primer ketiga memiliki panjang $20 \mathrm{bp}$, Tm left $56.97^{\circ} \mathrm{C}$, Tm right $57.06{ }^{\circ} \mathrm{C}$ dan $\mathrm{GC} \% 42.86$ dengan panjang produk amplifikasi sebesar 1133. Hasil primer BLAST menunjukkan primer ini cukup spesifik yaitu hanya mengenali gen MRPA T. brucei (XM_841956.1, AC091701.3, AC091701.3). Semua primer yang dinyatakan memenuhi persyaratan ukuran, Tm dan persentase GC (Tabel 1) selanjutnya dilakukan optimasi secara laboratorium.

Tabel 1. Hasil desain primer online dan analisis primer BLAST

\begin{tabular}{lcclccc}
\hline No & Oligo & $\underline{\text { Start }}$ & Panjang & Tm & GC $\%$ & Sekuen \\
\hline 1 & Left Primer & 1814 & $21 \mathrm{bp}$ & $60.00{ }^{\circ} \mathrm{C}$ & 47.62 & CCTCACTTTGTGGCCGTATAA \\
& Right Primer & 2826 & $21 \mathrm{bp}$ & $59.98^{\circ} \mathrm{C}$ & 47.62 & ATCCACAGCCTCCGTATTCTT \\
2 & Left Primer & 1691 & $21 \mathrm{bp}$ & $56.97^{\circ} \mathrm{C}$ & 42.86 & TACTGAACTTCTTGCCACACA \\
& Right Primer & 2904 & $21 \mathrm{bp}$ & $57.06^{\circ} \mathrm{C}$ & 42.86 & ACATGCACCAACATACCTCTT \\
3 & Left Primer & 1689 & $20 \mathrm{bp}$ & $56.97^{\circ} \mathrm{C}$ & 42.86 & CTGAACTTCTTGCCACACAG \\
& Right Primer & 2902 & $20 \mathrm{bp}$ & $57.06^{\circ} \mathrm{C}$ & 42.86 & CACAGCCTCCGTATTCTTCT \\
\hline
\end{tabular}


Optimasi dilakukan menggunakan PCR dengan pengaturan suhu annealing yang digunakan dihitung berdasarkan $(\mathrm{Tm}-5){ }^{\circ} \mathrm{C}$ sampai dengan $(\mathrm{Tm}+5){ }^{\circ} \mathrm{C}$. Hasil optimasi ketiga primer menunjukkan primer pertama optimal pada suhu $59.5{ }^{\circ} \mathrm{C}$, primer kedua optimal pada suhu $58{ }^{\circ} \mathrm{C}$, primer ketiga tidak dapat ditemukan suhu optimalnya. Gambar 3 menunjukan hasil optimasi primer menggunakan PCR, pada primer pertama dan kedua menunjukkan adanya pita DNA yang jelas, sedangkan pada primer ketiga tidak tampak adanya pita DNA. Proses optimasi annealing masingmasing primer dilakukan beberapa kali untuk mendapatkan hasil yang standard atau sama setiap pengulangan. Pada primer pertama dapat dimungkinkan lebih stabil dikarenakan memiliki GC persentase yang paling tinggi yaitu 47.62\% sehingga menunjukkan pita DNA yang jelas, hal ini dikarenakan nilai GC menunjukkan ikatan yang lebih kuat antara primer dan DNA template (Dewi et al., 2020; McPherson \& Møller, 2007; Suryanti et al., 2019; Ye et al., 2012).

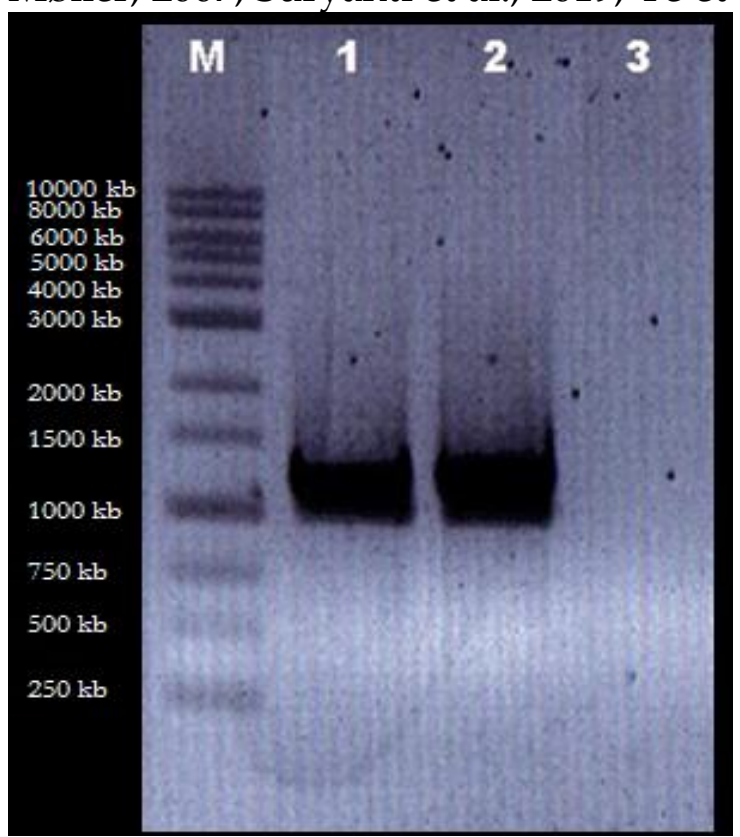

Gambar 3. Hasil optimasi annealing ketiga primer, (M) Marker $1 \mathrm{~kb}$, (1) hasil amplifikasi primer pertama, (2) hasil amplifikasi primer kedua, (3) hasil amplifikasi primer ketiga

Pada primer kedua juga menunjukkan hasil yang sama dengan pita yang terlihat, namun pada primer ketiga hasil yang didapatkan tidak konsisten bahkan tidak terlihat pita DNA. Hal ini dimungkinkan karena rendahnya nilai GC dibandingkan kedua primer lainnya dan juga perbedaan area pengenalan primer yang mungkin tidak dapat mengenali DNA template (Handoyo \& Rudiretna, 2000; McPherson \& Møller, 2007) dari gen MRPA T. evansi mengingat desain primer diambil dari gen MRPA T. brucei sehingga tidak semua susunan gennya sama (Lun, Li, Chen, Lu, \& Zhu, 2004). Sekuen gen MRPA T. brucei dijadikan template awal desain primer dikarenakan T. brucei memiliki kekerabatan yang sangat dekat dengan T. evansi (Nuryady, Widayanti, Nurcahyo, Fadjrinatha, \& Ahmad Fahrurrozi, 2019).

Hasil optimasi primer pada penelitian ini dapat dijadikan kajian sebagai sumber belajar, dikarenakan umumnya guru-guru kurang begitu percaya diri atau bahkan kesulitan dalam menjelaskan materi terkait dengan bahasan molekuler (Boulay et al., 2010). Untuk kebanyakan guru biologi, biokimia dan biologi molekuler sangat sulit. Buku teks yang mereka miliki dan pelajari tidak dapat memberikan informasi mutakhir, sementara akses ke jurnal penelitian cukup mahal serta relatif minim pengalaman. Hal ini menjadi tantangan bagi guru, dan walau bagaimanapun guru 
harus terus mengembangkan kompetensi mereka (Dolan \& Collins, 2015; Knight \& Wood, 2005; Veselinovska, Gudeva, \& Djokic, 2011; Wood, 1984). Guru-termasuk guru IPA/Biologi-memainkan peran penting dalam pembelajaran (Angin, 2020; Cahyono, 2020; Pantiwati \& Nyono, 2020; Zalsalina, Palupi, \& Riyaningsih, 2020), termasuk pembelajaran biologi molekuler yang kaya teknologi saat ini yang secara signifikan mempengaruhi pembelajaran siswa. Untuk alasan inilah saatnya bagi siswa sekolah menengah, untuk menyadari bahwa tanggung jawab mereka terhadap subjek telah berubah, karena adanya tren terbaru dalam informasi dan komunikasi (Sarkar \& Sarkar, 2016).

Hal ini sangat penting menjadi bahan kajian dikarenakan pada pembahasan Biologi molekuler seorang guru juga harus menjelaskan terkait hal-hal yang berkaitan dengan PCR misalkan pembahasan apa itu primer, dan bagaimana cara mendesain primer (Wardoyo, Sabrina, \& Suryani, 2020). Sebagai upaya mengembangkan keterampilan praktis guru sekolah menengah, guru juga perlu membahas materi teknologi DNA, integrate DNA science and technology (Miller, Sass, Wong, \& Nienhuis, 2004), teori tentang isolasi DNA, reaksi berantai polimerase, dan elektroforesis dilakukan di ruang kelas. Sementara itu di laboratorium, penggunaan peralatan biologi molekuler, elektroforesis, hasil interpretasi pita DNA elektroforesis, dan NCBI dilakukan oleh para guru yang dibantu oleh asisten laboratorium (Aryani, Nugroho, Manurung, \& Prahastika, 2018). Pemodelan molekul juga dipilih sebagai pusat atau inti pembelajaran karena melibatkan semua disiplin ilmu (Taly, Nitti, Baaden, \& Pasquali, 2019). Siswa juga dapat memperoleh pengalaman langsung dengan program grafis untuk menjelajahi aspek struktural sistem makromolekul (Canning \& Cox, 2001).

Hal ini menjadi penting untuk diaplikasikan menjadi sumber belajar dikarenakan pada beberapa profil lulusan LPTK khususnya pendidikan biologi salah satu profil lulusan yang harus dicapai selain menjadi guru adalah menjadi wirausaha dan peneliti (National Research Council, 2003). Aspek peneliti dalam profil lulusan perguruan tinggi menjadi hal yang sangat mandatory agar para mahasiswa pendidikan biologi lebih memahami proses-proses dalam pekerjaan molekuler. Pekerjaan bidang molekuler saat ini merupakan bidang yang paling berkembang (Nurhayati \& Darmawati, 2019), sehingga apabila mahasiswa diharapkan menjadi peneliti maka penerapan pembelajaran molekuler seperti desain dan optimasi primer harus diaplikasikan sebagai sumber belajar. Oleh karena itu, mahasiswa dapat mengaplikasikan cara mendesain dan optimasi PCR untuk berbagai pekerjaan molekuler yang berhubungan dengan PCR di masa yang akan datang.

\section{KESIMPULAN}

Desain primer onlie didapatkan tiga primer yang sesuai dengan persyaratan dan juga hasil primer BLAST menunjukkan ketiga primer tersebut spesifik berikatan dengan gen MRPA T. brucei, namun hasil optimasi menunjukkan primer pertama dan kedua merupakan primer yang dapat digunakan untuk penelitian amplifikasi gen MRPA T. evansi dengan suhu annealing masing-masing yaitu $59.5^{\circ} \mathrm{C}$ dan $58^{\circ} \mathrm{C}$. Hasil penelitian ini sangat penting untuk diaplikasikan sebagai sumber belajar mahasiswa pendidikan biologi, agar mahasiswa pendidikan biologi lebih memahami pekerjaan molekuler seperti desain dan optimasi PCR agar menjadi lulusan sesuai cita-cita program studi salah satunya yaitu menjadi peneliti. 


\section{SARAN}

Kajian ini merupakan titik awal rekomendasi fokus penelitian terkait dengan optimasi primer dan bagaimana kaitanya dengan pengembangan kompetensi calon guru biologi. Kajian ini perlu dilajutkan dalam bentuk model-model pembelajaran atau pengembangan sumber belajar berbasis desain dan optimasi primer dalam biologi. Mahasiswa dan peneliti lain dapat mengembangkan desain dan optimasi primer untuk penelitian molekuler lainnya dengan bahan atau sampel yang lebih spesifik.

\section{UCAPAN TERIMA KASIH}

Terima kasih kami sampaikan kepada Dekan Fakultas Keguruan dan Ilmu Pendidikan serta Rektor Universitas Muhammadiyah Malang yang terus mendorong pengembangan kajian dan diskusi terkait dengan bioteknologi, biologi molekuler, dan implementasinya dalam pembelajaran sehingga memperkaya bahan yang dapat ditranfer kepada para mahasiswa calon guru biologi.

\section{DAFTAR PUSTAKA}

Angin, R. Z. P. (2020). Penerapan STEM Pada Pembelajaran IPA Materi Bioteknologi. Prosiding Seminar Nasional V 2019, 300-307. Malang, Indonesia: Pendidikan Biologi FKIP Universitas Muhammadiyah Malang.

Aryani, R., Nugroho, R. A., Manurung, H., \& Prahastika, W. (2018). Enhancing biology molecular laboratory practice for senior high school of biology teachers from Samarinda and Tenggarong city. Pelita Eksakta, 1(2), 75-81. https://doi.org/10.24036/pelitaeksakta/vol1-iss2/29

Bass, D., Stentiford, G. D., Littlewood, D. T. J., \& Hartikainen, H. (2015). Diverse applications of environmental DNA methods in parasitology. Trends in Parasitology, 31(10), 499-513. https://doi.org/10.1016/j.pt.2015.06.013

Bedwell, M. E., \& Goldberg, C. S. (2020). Spatial and temporal patterns of environmental DNA detection to inform sampling protocols in lentic and lotic systems. Ecology and Evolution, 10(3), 1602-1612. https:/ / doi.org/10.1002/ece3.6014

Boulay, R., Parisky, A., \& Campbell, C. (2010). Developing teachers' understanding of molecular biology: Building a foundation for students. ASCILITE 2010 - The Australasian Society for Computers in Learning in Tertiary Education, 119-128.

Cahyono, E. (2020). Kajian kompetensi guru tentang laboratorium IPA di SMP dan SMA. Prosiding Seminar Nasional V 2019, 362-367. Malang: Pendidikan Biologi FKIP Universitas Muhammadiyah Malang.

Canning, D. R., \& Cox, J. R. (2001). Teaching the structural nature of biological molecules: Molecular visualization in the classroom and in the hands of students. Chemistry Education: Research and Practice in Europe, 2(2), 109-122. https://doi.org/10.1039/b1rp90013g

Delespaux, V., Geysen, D., Majiwa, P. A. O., \& Geerts, S. (2005). Identification of a genetic marker for isometamidium chloride resistance in Trypanosoma congolense. 35, 235-243. https://doi.org/10.1016/j.ijpara.2004.11.009

Dewi, D., Wardhana, A., Ekawasti, F., \& Sawitri, D. (2020). Perbandingan lima set primer untuk mendeteksi Trypanosoma evansi pada mencit dengan teknik Polymerase Chain Reaction (PCR). Medpub.Litbang.Pertanian.Go.Id, 178-188.

Dolan, E. L., \& Collins, J. P. (2015). We must teach more effectively: Here are four ways to get started. Molecular Biology of the Cell, 26(12), 2151-2155. 
https:/ / doi.org/10.1091/mbc.E13-11-0675

Handoyo, D., \& Rudiretna, A. (2000). Prinsip umum dan pelaksanaan polymerase chain reaction (PCR) [general principles and implementation of polymerase chain reaction]. Unitas, 9(1), 17-29.

Keskin, B., \& Özay Köse, E. (2017). Misconceptions of prospective biology teachers about theory of evolution. Balikesirnef, 11(2), 212-242. https://doi.org/10.17522/balikesirnef.373344

Knight, J. K., \& Wood, W. B. (2005). Teaching more by lecturing less. Cell Biology Education, 4, 298-310. https://doi.org/10.1187/05

Kochin, B. F., Bull, J. J., \& Antia, R. (2010). Parasite evolution and life history theory. PLoS Biology, 8(10), 10-13. https://doi.org/10.1371/journal.pbio.1000524

Lun, Z.-R., Li, A.-X., Chen, X.-G., Lu, L.-X., \& Zhu, X.-Q. (2004). Molecular profiles of Trypanosoma brucei, T. evansi and T. equiperdum stocks revealed by the random amplified polymorphic DNA method. Parasitology Research, 92(4), 335-340.

Maryuningsih, Y., Hidayat, T., Riandi, R., \& Rustaman, N. Y. (2020). The critical thinking skills of biology teacher candidates toward the ethical issues. JPBI (Jurnal Pendidikan Biologi Indonesia), 6(1), 65-74.

McPherson, M., \& Møller, S. (2007). Polimerase Chain Reaction (PCR). Taylor \& Francis. Miller, J. S., Sass, M. E., Wong, S. J., \& Nienhuis, J. (2004). Micropipetting: An important laboratory skill for molecular biology. The American Biology Teacher, 66(4), 291-296. https:/ / doi.org/10.2307/4451672

National Research Council. (2003). BIO2010: Transforming undergraduate education for future research biologists. Washington, D.C: National Academies Press.

National Science Teachers Association. (2003). Standards for science teacher preparation. Retrieved from https:/ / digitalcommons.unl.edu/cgi/viewcontent.cgi?article=1085\&context=te achlearnfacpub

Njiru, Z. K., Constantine, C. C., Guya, S., Crowther, J., Kiragu, J. M., Thompson, R. C. A., \& Dávila, A. M. R. (2005). The use of ITS1 rDNA PCR in detecting pathogenic African trypanosomes. Parasitology Research, 95(3), 186-192.

Nurhayati, B., \& Darmawati, S. (2019). Biologi sel dan molekuler: Bahan ajar teknologi labotarium medis. Jakarta: Indo. Kemkes. BPPSDM.

Nurlaila, L., Sriyati, S., \& Riandi. (2017). Analizing student biology education misconception and scientific argumentation ability using diagnostic question clusters (Dqcs) of molecular genetic concept. Journal of Physics: Conference Series, 812, 012112. https://doi.org/10.1088/1742-6596/812/1/012112

Nuryady, M. M., Widayanti, R., Nurcahyo, R. W., Fadjrinatha, B., \& Ahmad Fahrurrozi, Z. S. (2019). Characterization and phylogenetic analysis of multidrugresistant protein-encoding genes in Trypanosoma evansi isolated from buffaloes in Ngawi district, Indonesia. Veterinary World, 12(10), 1573-1577. https://doi.org/10.14202/vetworld.2019.1573-1577

Olander, C., \& Olander, M. H. (2013). Professional development through the use of learning study: Contributions to pedagogical content knowledge in biology. Procedia -Social and Behavioral Sciences, 89, 205-212.

Pantiwati, Y., \& Nyono, N. (2020). Asesmen Autentik dalam Kegiatan Praktik Pembelajaran sains. Prosiding Seminar Nasional Pendidikan Biologi V 2019, 385-392. Malang: Pendidikan Biologi FKIP Universitas Muhammadiyah Malang.

Sambrook, J., R. D. . (2001). Molecular Cloning: A Laboratory Manual (3th editio). New York: Cold Spring Harbor Laboratory press. 
Sarkar, S., \& Sarkar, S. (2016). A new approach to teach molecular biology in high school using Python. 2016 IEEE Region 10 Humanitarian Technology Conference (R10-HTC), 1-5. Retrieved from 10.1109/R10-HTC.2016.7906784

Scottish Qualifications Authority. (2019). Higher biology. Retrieved from https://www.sqa.org.uk/files_ccc/HigherCourseSpecBiology.pdf

Suryanti, E., Fitriani, A., Redjeki, S., \& Riandi, R. (2019). Identifikasi kesulitan mahasiswa dalam pembelajaran biologi molekuler berstrategi modified free inquiry. Perspektif Pendidikan Dan Keguruan, 10(2), 37-47.

Taly, A., Nitti, F., Baaden, M., \& Pasquali, S. (2019). Molecular modelling as the spark for active learning approaches for interdisciplinary biology teaching. Interface Focus, 9(3). https://doi.org/10.1098/rsfs.2018.0065

Veselinovska, S. S., Gudeva, L. K., \& Djokic, M. (2011). Applying appropriates methods for teaching cell biology. Procedia - Social and Behavioral Sciences, 15, 28372842. https://doi.org/10.1016/j.sbspro.2011.04.199

Wardhana, A. H., Merlina, Y., \& Subekti, D. T. (2014). Aktivitas Antitrypanosoma Ekstrak Air Daun Tithonia diversifolia A. Gray dan Artemisia annua L. terhadap Trypanosoma evansi secara in vitro. JITV, 19(2).

Wardoyo, E. H., Sabrina, Y., \& Suryani, D. (2020). Pengenalan teknik molekuler polymerase chain reaction ( PCR ) pada guru biologi SMA di Kota Mataram. 1(2), 139143.

Wood, E. J. (1984). Biochemistry is a difficult subject for both student and teacher. Biochemical Education, 18(4), 170-172.

Ye, J., Coulouris, G., Zaretskaya, I., Cutcutache, I., Rozen, S., \& Madden, T. L. (2012). Primer-BLAST: A tool to design target-specific primers for polymerase chain reaction. BMC Bioinformatics, 13(1), 134.

Yuwono, T. (2006). Teori dan Aplikasi Polymerase Chain Reaction; panduan eksperimen PCR untuk memecahkan masalah biologi terkini. Yogyakarta: Penerbit Andi, 89.

Zalsalina, R., Palupi, G., \& Riyaningsih, D. (2020). Penilaian keterampilan abad ke-21. Prosiding Seminar Nasional V 2019, 340-346. Malang: Pendidikan Biologi FKIP Universitas Muhammadiyah Malang. 